\title{
Serological evidence of infectious salmon anaemia virus (ISAV) infection in farmed fishes, using an indirect enzyme-linked immunosorbent assay (ELISA)
}

\author{
Molly T. Kibenge ${ }^{1}$, Beatriz Opazo ${ }^{2}$, Alejandro H. Rojas ${ }^{2}$, Frederick S. B. Kibenge ${ }^{1, *}$ \\ ${ }^{1}$ Department of Pathology and Microbiology, Atlantic Veterinary College, University of Prince Edward Island, 550 University \\ Avenue, Charlottetown, Prince Edward Island C1A 4P3, Canada \\ ${ }^{2}$ Fundación Chile, Panamericana Sur 581, Puerto Montt, Chile
}

\begin{abstract}
Antibody detection tests are rarely used for diagnostic purposes in fish diseases. Infectious salmon anaemia (ISA) caused by ISA virus (ISAV) is an emerging disease of Atlantic salmon Salmo salar L. The virus has also been isolated from diseased coho salmon Oncorhynchus kisutch in Chile. An indirect enzyme-linked immunosorbent assay (ELISA) that should facilitate serodiagnosis of ISAV infection, the study of epidemiology, and the control of ISA in farmed fishes has been developed using purified ISAV as the coating antigen, and monoclonal antibodies that detect fish immunoglobulins bound to the antigen on the plate. Application of the test to a random sample of farmed Atlantic salmon from the Bay of Fundy, New Brunswick, Canada, positively identified 5 of the 7 ISAV RT-PCRpositive fish, and all 10 RT-PCR-negative fish were also negative in the ELISA. Some RT-PCR-negative fish had an elevated non-specific antibody reactivity suggestive of chronic infection or resistance to ISAV. This test was also able to detect 11 of the 14 coho salmon pooled serum samples from a clinically affected farm in Chile that were positive by the virus neutralization (VN) test, and 2 of the 4 VN-negative samples. We conclude that this ELISA would be suitable as a routine test for ISAV infection or for assessing ISAV vaccine efficacy before placing smolts in sea cages, and for testing fishes in sea cages to detect level of resistance to ISA. The assay enables vaccination in combination with depopulation control methods.
\end{abstract}

KEY WORDS: ISAV · Indirect ELISA · Atlantic salmon antibody · Coho salmon antibody

\section{INTRODUCTION}

Infectious salmon anaemia (ISA) caused by ISA virus (ISAV), an orthomyxo-like virus, is an important viral pathogen of fishes. It causes ISA in marine-farmed Atlantic salmon Salmo salar L. characterized grossly by exophthalmia, pale gills and ascites (Thorud \& Djupvik 1988), and microscopically by haemorrhagic liver necrosis (Evensen et al. 1991) and renal interstitial haemorrhage and tubular nephrosis (Mullins et al.

*Corresponding author. E-mail: kibenge@upei.ca
1998). The disease was first identified in Norway in 1984 (Thorud \& Djupvik 1988) and subsequently in New Brunswick, Canada, in 1996 (Byrne et al. 1998, Mullins et al. 1998, Lovely et al. 1999), in Scotland in 1998 (Rodger \& Richards 1998), in Nova Scotia, Canada, in 2000 (Ritchie et al. 2001), in the Faroe Islands, Denmark, in 2000 (Anonymous 2000a), and most recently in Maine, USA, in 2000 (Bouchard et al. 2001). The virus has also recently been detected in diseased coho salmon in Chile (Kibenge et al. 2001), and in apparently normal wild fish (sea trout, Atlantic salmon, and brown trout) from Scotland (Raynard et al. 2001). Sea trout, brown trout and rainbow trout have 
been shown experimentally to be asymptomatic carriers of the virus (Nylund et al. 1994, 1995, 1997). Farmed Atlantic salmon that recover from clinical ISA continue to shed virus for long periods of time, but detection of ISAV in carrier fish required the use of reverse transcription-polymerase chain reaction (RTPCR) (Devold et al. 2000), suggesting that the viral RNA is not abundant. The morphological, biochemical and replication properties of ISAV indicate strongly that it is a member of the virus family Orthomyxoviridae (Kim \& Leong 1999).

Laboratory diagnostic methods used to confirm a diagnosis of ISA are still subject to debate by the regulatory authorities in countries where ISA is known to occur, because of the stringent disease control measures in place. Thus, currently, laboratory diagnosis of ISA includes the isolation of ISAV in the salmon head kidney (SHK-1) cell line (Dannevig et al. 1995) and/or the CHSE-214 cell line (Bouchard et al. 1999, Kibenge et al. 2000a) and electron microscopic examination of a positive isolate, the use of RT-PCR (Mjaaland et al. 1997, Rimstad et al. 1999, Devold et al. 2000, Kibenge et al. $2000 \mathrm{~b}$ ), and an indirect fluorescent antibody test (IFAT) on positive virus isolates or on tissue samples from suspected fish (Falk et al. 1998). Thus, no serological test is currently used in diagnosis of ISA, and although vaccination is permitted in areas like the Bay of Fundy, New Brunswick, detection of ISAV infection is sufficient to trigger a decision to depopulate the affected farm.

In contrast to diagnostic tests for infectious diseases of mammals and birds (Anonymous 2000b), confirmation of exposure to a disease agent by detection of antibody to the agent is rarely, if ever, used in disease diagnosis of aquatic animals, although it has been known for a long time that fish immunoglobulins possessed a range of serological activities similar to those shown by mammalian immunoglobulins (Corbel 1975). Present limitations are due not only to lack of experience and difficulties with interpretation of serological test results (Hattenberger-Baudouy et al. 1995), but also to discrete features of the humoral immune response in fishes (Corbel 1975, Dorson 1981) such as a predominant IgM subtype (Marchalonis 1971) and the absence of switch by B-lymphocytes to secretion of high-affinity binding antibodies (Wilson \& Warr 1992).

Fish serology (for example virus neutralization [VN] and antibody enzyme-linked immunosorbent assay [ELISA]) could be of importance in detecting asymptomatic virus carriers among fish stocks for various viral diseases, but it is not yet validated, and no antibody detection test has yet been approved by regulatory authorities as the official procedure for routine diagnostic purposes. There remains a need for diagnostic approaches other than direct virus diagnostic methods for the assessment of fish populations relevant to infec- tion with virus pathogens, and especially those which are responsible for notifiable diseases. In this paper we report the development of a highly specific ELISA for detection of fish antibodies to ISAV. Examination of sera from Atlantic salmon following experimental infection with ISAV showed that specific antibody was present beginning at $6 \mathrm{wk}$ post-infection. This indicated that the assay could be used as a routine laboratory test for detection of ISAV infection, particularly when the virus is notoriously difficult to isolate from clinical specimens, as in farmed coho salmon in Chile (Kibenge et al. 2001). Where vaccination is not performed, such as in wild fishes, the test can detect asymptomatic ISAV carriers.

\section{MATERIALS AND METHODS}

Preparation of purified virus antigen. Infectious salmon anaemia virus strains RPC/NB 990-02-4 and RPC/NB 970-877-2 were propagated in SHK-1 cell line as previously described (Kibenge et al. 2000a). The virus was concentrated using double ammonium sulphate precipitation followed by overnight dialysis against TNE $(10 \mathrm{mM}$ Tris- $\mathrm{HCl}, 0.1 \mathrm{M} \mathrm{NaCl}, 1 \mathrm{mM}$ EDTA, pH 7.5) buffer. The dialyzed virus was purified by ultracentrifugation at $95000 \times g$ for $1 \mathrm{~h}$ at $4^{\circ} \mathrm{C}$, using a Ficoll 400-step gradient (25 and $10 \%$ ) in a SW40 rotor (Beckman Canada), and the extracted bands were pelleted through $20 \%$ sucrose. The virus pellet was dissolved in TNE buffer and the protein concentration was estimated by spectrophotometry at $280 \mathrm{~nm}$. The virus solution was then aliquoted prior to storage at $-80^{\circ} \mathrm{C}$ until used as the virus antigen to coat 96-well plates. The purity of the virus was checked by electrophoresis on $12.5 \%$ SDS-polyacrylamide gels. The virus preparation was judged to be pure when only the 4 characteristic viral protein bands at $74,53,43$, and $26.5 \mathrm{kDa}$ were visible in Coomassie blue-stained gels (Kibenge et al. 2000a). A lysate of uninfected SHK-1 cells was adsorbed to some ELISA plate wells as a control for non-specific binding of the fish antibodies.

Fish serum samples. Standard procedures for blood collection, processing and storage of serum were used in this study. Thus, blood was collected from the tail vein of the fish and allowed to clot overnight at $4^{\circ} \mathrm{C}$. It was then centrifuged at low speed to collect the serum. The harvested serum was stored at $-20^{\circ} \mathrm{C}$ prior to use. Three groups of Atlantic salmon Salmo salar sera were used. The first group consisted of one known positive Atlantic salmon serum field sample (identified on the basis of a positive VN test in another study) and one known negative Atlantic salmon serum (obtained from experimental fish that had never been in natural seawater). These sera were used to optimize the assay 
reagents and the protocol. The second group were 4 individual fish serum samples collected by terminal bleeding from fish at 0, 2, 4 and 6 wk following experimental infection with ISAV (Kibenge et al. 2000b). These were used to assess the analytical sensitivity of the ELISA system by end-point dilution analysis. The third group of Atlantic salmon sera consisted of 37 fish serum samples collected from various fish farms in the Bay of Fundy, Canada, on 2 separate occasions (17 field serum samples designated here as belonging to Group 3A, and 20 as belonging to Group 3B). In Group 3A, the fish sampled were also tested for ISAV by RTPCR using primers to ISAV RNA Segment 8 as previously described (Kibenge et al. 2000a).

For this study, 20 coho salmon sera were used: 1 serum sample was a known negative coho salmon (Oncorhynchus kisutch) serum sample obtained from aquarium-raised experimental fish at the Atlantic Veterinary College Aquatic Animal Facility (courtesy of AVC Inc.); the remaining 19 coho salmon sera were pools of up to 5 fish each, from a clinically affected fish farm in Chile. All the serum samples were initially tested using the VN test in either the TO cell line or the CHSE-214 cell line in order to select the known positive and negative controls for use in ELISA. Virus neutralization antibody titres ranging from 1:40 to 1:3840 were detected in the samples when tested using the TO cell line (data not shown). However, it was difficult to determine the real end points in the TO cell line because the serum samples were frequently toxic at lower serum dilutions. It was therefore decided to use the VN titres obtained using the CHSE214 cell line to select the known positive and negative controls for use in ELISA.

All samples were heat-inactivated at $56^{\circ} \mathrm{C}$ for $30 \mathrm{~min}$ prior to use.

Virus neutralization test. The VN test was carried out on cell monolayers of either the TO cell line (Wergeland \& Jakobsen 2001) or the CHSE-214 cell line (Lannan et al. 1984) grown in 48-well culture plates. The TO cell monolayers were grown at room temperature $\left(22^{\circ} \mathrm{C}\right)$ in HMEM (Eagle's minimum essential medium containing Hank's salts: BioWhittaker) supplemented with $292 \mu \mathrm{g} \mathrm{ml} \mathrm{m}^{-1}$ L-glutamine (Sigma), $1 \%$ (v/v) non-essential amino acids (NEAA) (Sigma), $100 \mu \mathrm{g} \mathrm{ml}^{-1}$ gentamicin (Sigma) and 10\% (v/v) foetal bovine serum (FBS). The CHSE-214 cells were grown at $16^{\circ} \mathrm{C}$ in $\mathrm{HMEM}$ containing $292 \mathrm{mM}$ L-glutamine (Invitrogen Life Technologies), supplemented with $100 \mathrm{U}$ penicillin, $100 \mu \mathrm{g} \mathrm{ml}^{-1}$ streptomycin and $0.25 \mu \mathrm{g} \mathrm{ml}^{-1}$ amphotericin B, with $10 \% \mathrm{FBS}$. In the maintenance medium for both cell lines, FBS was reduced to $5 \%$. To set up a VN test, $100 \mu \mathrm{l}$ of serial 2fold dilutions of fish serum and an equal volume of virus suspension containing 100 TCID $_{50}$ of ISAV Strain RPC/NB 990-02-4 were added to cell monolayers drained of medium, and incubated at room temperature for $1 \mathrm{~h}$ before addition of $500 \mu \mathrm{l}$ of fresh maintenance medium to each well. After $10 \mathrm{~d}$ incubation of TO cells (21 d for the CHSE-214 cell line) at $16^{\circ} \mathrm{C}$, cultures were examined microscopically for cytopathic effects (CPE) to determine the VN test results.

Indirect ELISA system. Different types of ELISA plates, coating antigen concentrations, blocking buffers, incubation periods and temperatures, and fish serum preparations were tested during preliminary experiments. The optimal conditions were then used as described. The ELISA plates (Falcon Pro Bind Assay plates, VWR) were coated with $1.0 \mu \mathrm{g}$ of virus antigen per well in $100 \mu$ l of $0.2 \mathrm{M}$ sodium carbonate-bicarbonate buffer, $\mathrm{pH} 9.6$, and incubated overnight at $4^{\circ} \mathrm{C}$ (Harlow \& Lane 1988). In order to ascertain the analytical specificity of the ELISA system, an uninfected SHK-1 cell lysate was used as the negative (or irrelevant) antigen at a concentration of $10 \mu \mathrm{g} \mathrm{ml}^{-1}$. Following overnight incubation, the plates were washed 3 times with Dulbecco's phosphatebuffered saline (PBS) with $0.05 \%$ (v/v) Tween 20 (T-PBS) and unbound sites were blocked by adding to each well $100 \mu \mathrm{l}$ of $3 \%(\mathrm{v} / \mathrm{v})$ normal goat serum in T-PBS and incubating at room temperature for $1 \mathrm{~h}$. The blocking medium was removed and the plates were washed as described above. Fish serum samples in 2-fold dilutions (from 1:10 to $1: 5120)$ made in T-PBS with $1 \%(\mathrm{v} / \mathrm{v})$ normal goat serum were added to the wells $(100 \mu l$ per well $)$ in triplicate and incubated at $16^{\circ} \mathrm{C}$ for $1.5 \mathrm{~h}$ (Arkoosh \& Kaattari 1990). On each plate a row of 'blank wells' received T-PBS instead of fish serum. These blank wells were used to determine the background optical density (OD) of the ELISA system. The ELISA plates were then quickly washed 3 times, followed by three $10 \mathrm{~min}$ washes. For Atlantic salmon samples, mouse monoclonal antibody IPA3D1 (Immuno-Precise Antibodies) to Atlantic salmon immunoglobulin, diluted 1:500 in T-PBS with $1 \%$ (v/v) normal goat serum, was added to all wells $\left(100 \mu \mathrm{l}\right.$ per well) and incubated at $37^{\circ} \mathrm{C}$ for $1 \mathrm{~h}$. For ELISA on coho salmon serum samples, mouse monoclonal antibody IPA2C7 (Immuno-Precise Antibodies) to rainbow trout immunoglobulin was used at a dilution of 1:1500 in T-PBS with $1 \%$ (v/v) normal goat serum (in preliminary tests it was established that Mab IPA2C7 does not recognize Atlantic salmon immunoglobulins but does recognize coho salmon immunoglobulins). The ELISA plates were washed as described above, then $100 \mu$ of goat anti-mouse $\operatorname{IgG}_{1}$ alkaline phosphatase-conjugate (Cedarlane Laboratories) diluted 1:1500 in T-PBS with $1 \%(\mathrm{v} / \mathrm{v})$ goat serum were added to each well and the plates were incubated for $1 \mathrm{~h}$ at $37^{\circ} \mathrm{C}$. The plates were again washed to remove unbound conjugate, and $100 \mu \mathrm{l}$ of the enzyme substrate $p$-nitrophenyl phosphate (Sigma) were added to each well. The plates were incubated for approximately $45 \mathrm{~min}$ at $37^{\circ} \mathrm{C}$ in the dark to de- 
velop optimal colour, and then the OD was read in an automated microtitre ELISA reader (Spectra $\mathrm{Max}^{\mathrm{TM}}$ 340) at $405 \mathrm{~nm}$ wavelength. In some cases, incubation was continued overnight at $37^{\circ} \mathrm{C}$ before taking a final reading. To determine the optimal incubation interval during which the OD reading would be proportional to the antibody concentration, readings were taken at $10 \mathrm{~min}$ intervals for $4 \mathrm{~h}$ and a final reading after $24 \mathrm{~h}$.

Indirect-competition ELISA. A competitive assay for indirect ELISA was set up using a rabbit anti-ISAV serum (Kibenge et al. 2000a) diluted 1:200 as the first antibody added to the virus antigen. After blocking the wells with $3 \%$ goat serum and washing the plates, $100 \mu \mathrm{l}$ of rabbit anti-ISAV serum (1:200) was added to all the wells and incubated at $16^{\circ} \mathrm{C}$ for $1.5 \mathrm{~h}$; then the plates were washed as described above, and known positive and negative Atlantic salmon sera were added to the wells and the rest of the assay was carried out as described above. The OD reading in the plates that were incubated with rabbit anti-ISAV serum were compared with those assayed without the addition of rabbit anti-ISAV serum.

Reverse transcription-polymerase chain reaction. Fish tissue samples were examined for the presence of ISAV nucleic acids by RT-PCR as previously described (Kibenge et al. 2000b). Briefly, viral RNA was extracted from $250 \mu \mathrm{l}$ volumes of tissue homogenates using TRIZOL LS Reagent (Invitrogen Life Technologies) following the manufacturer's protocol. The PCR primers targeted ISAV RNA Segment 8, consisted of 5'-GAA GAG TCA GGA TGC CAA GAC G-3' (FA-3, sense, Nucleotide Positions 342 to 363) and 5'-GAA GTC GAT GAT CTG CAG CGA-3' (RA-3, antisense, Nucleotide Positions 532 to 552), and yielded a PCR product of 220 bp (Devold et al. 2000; nucleotide positions based on GenBank Accession No. AF312317). One-step RT-PCR was carried out using the Titan ${ }^{\mathrm{TM}}$ One Tube RT-PCR System kit (Roche Molecular Biochemicals). The RT-PCR was performed in a PTC-200 DNA Engine Peltier thermal cycler (MJ Research). Cycling conditions consisted of 1 cycle of cDNA synthesis and pre-denaturation at $55^{\circ} \mathrm{C}$ for $30 \mathrm{~min}$ and $94^{\circ} \mathrm{C}$ for $2 \mathrm{~min}$, followed by $40 \mathrm{am}$ plification cycles each consisting of denaturation at $94^{\circ} \mathrm{C}$ for $30 \mathrm{~s}$, annealing at $61^{\circ} \mathrm{C}$ for $45 \mathrm{~s}$, and extension at $72^{\circ} \mathrm{C}$ for $90 \mathrm{~s}$, with a final extension at $72^{\circ} \mathrm{C}$ for $10 \mathrm{~min}$. PCR products were resolved by electrophoresis on a $2 \%$ agarose gel and visualized under $304 \mathrm{~nm}$ UV light after staining with ethidium bromide (Sambrook et al. 1989).

Statistical analysis. The average OD of the blank wells on each ELISA plate was subtracted as background noise from the OD of each well on the plate. For each dilution of a serum sample, the results are reported as the corrected mean $\pm \mathrm{SD}(\mathrm{n}=3)$, and the mean difference between assay signals from the virus antigen and cell antigen was assessed using unpaired $t$-tests. The end point for the assay was calculated from the mean OD plus 2 standard deviations of the positive control serum when reacted against the cellular antigens.

\section{RESULTS}

\section{Determination of antigen concentration to use}

The working concentration of antigen adsorbed to the plate was determined by testing $2.5,5,7.5$, and $10 \mu \mathrm{g} \mathrm{ml} \mathrm{m}^{-1}$ of virus antigen using ISAV Isolates RPC/NB 990-02-4 and RPC/NB 970-877-2. Isolate RPC/NB 970-877-2 is a CHSE-negative phenotype, whereas RPC/NB-990-02-4 is a CHSE-positive phenotype. As shown in Fig. 1, no difference was observed in the detection level among all 4 virus antigen concentrations within each isolate and among the 2 ISAV isolates. Both virus antigens detected the same serum titer, 1:20, as the highest serum dilution without loss of signal, although the RPC/NB 990-02-4 antigen was
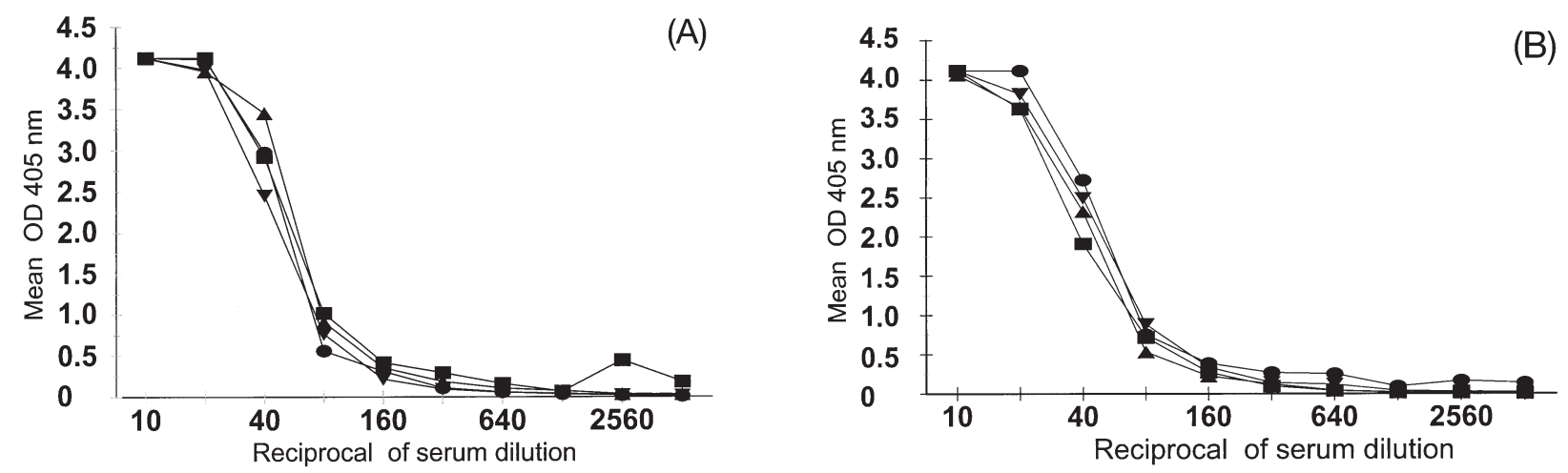

Fig. 1. Determination of the coating concentration of virus antigen for use in indirect ELISA for fish antibodies to ISAV. (A) ISAV isolate RPC/NB 990-02-4; (B) ISAV isolate RPC/NB-970877-2. The following virus antigen concentrations $\left(\mu \mathrm{g} \mathrm{ml}{ }^{-1}\right)$ were tested: $2.5(\bullet), 5(\mathbf{\Delta}), 7.5(\mathbf{\square})$, and $10(\mathbf{\nabla})$. OD: optical density 
marginally better. Use of a blank (i.e. no fish serum added) showed the assay to have very low background signals with all antigen concentrations used. The virus antigen prepared from Isolate RPC/NB-990-02-4 was used at the arbitrary concentration of $10 \mu \mathrm{g} \mathrm{ml}^{-1}$ (i.e. $1.0 \mu \mathrm{g} \mathrm{well}{ }^{-1}$ ) as the positive antigen.

\section{Determination of optimum incubation time for colour development}

In order to determine the optimum substrate incubation time during which the OD reading would be proportional to the antibody concentration, readings were taken at $10 \mathrm{~min}$ intervals for $4 \mathrm{~h}$, and a final reading after
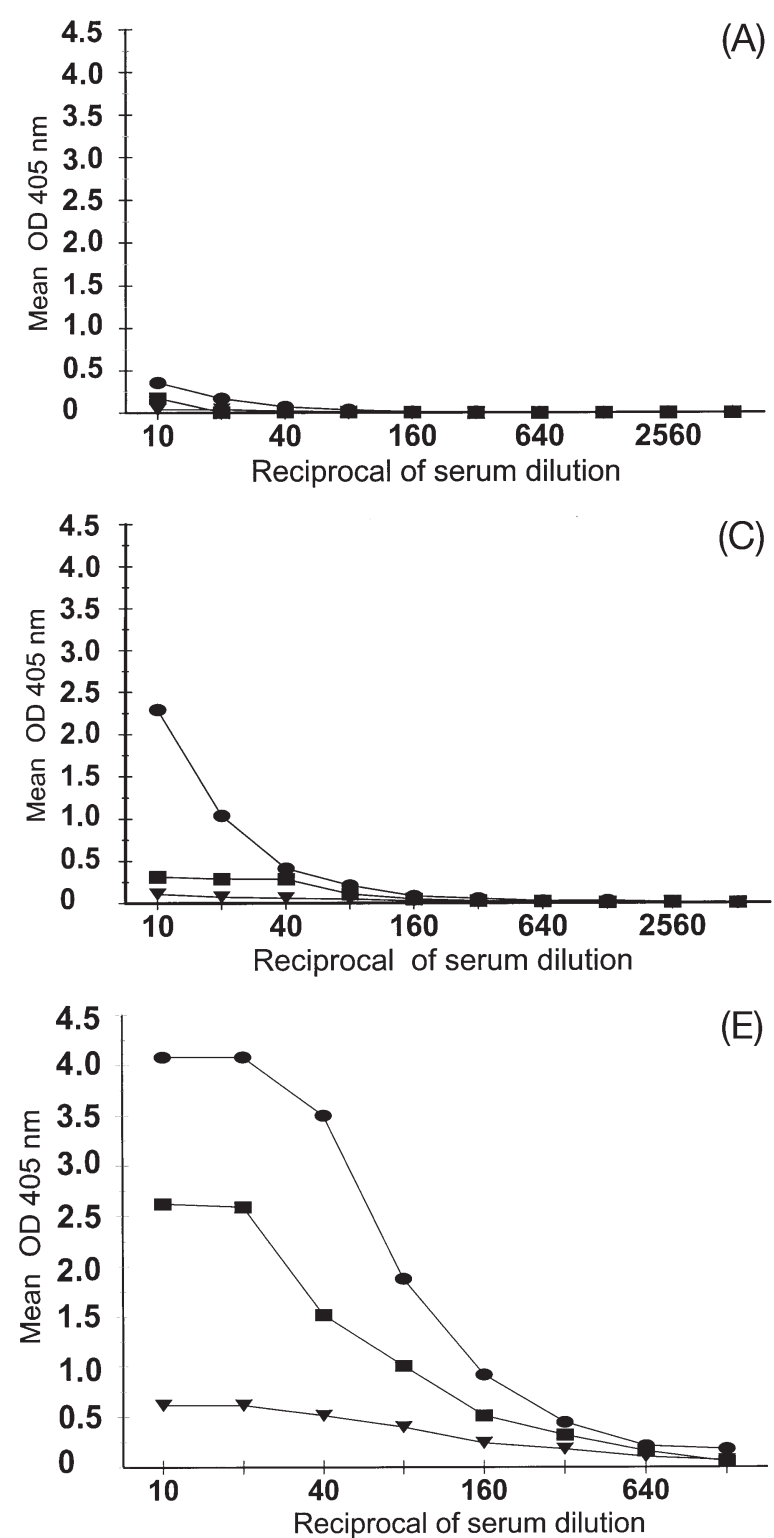

24 h. Fig. 2 shows that the rate of colour development was proportional to the amount of antibody in the fish serum sample for at least $2 \mathrm{~h}$ of incubation in samples with high antibody levels. In contrast, samples with low antibody levels showed little or no change in the rate of colour development after incubations of up to $4 \mathrm{~h}$, but showed significant difference from negative control sera after overnight incubation. All serum samples were read after $45 \mathrm{~min}$, and overnight incubations at $37^{\circ} \mathrm{C}$. After $45 \mathrm{~min}$ of incubation, the antibody titer of the strongly positive Atlantic salmon serum was 1:640, with a corrected mean OD of $0.4 \pm 0.02$ against the virus antigen. The antibody titer estimated with overnight incubation was 1:1280, with a corrected mean OD of $0.35 \pm$ 0.04 against the virus antigen (Table 1 ).
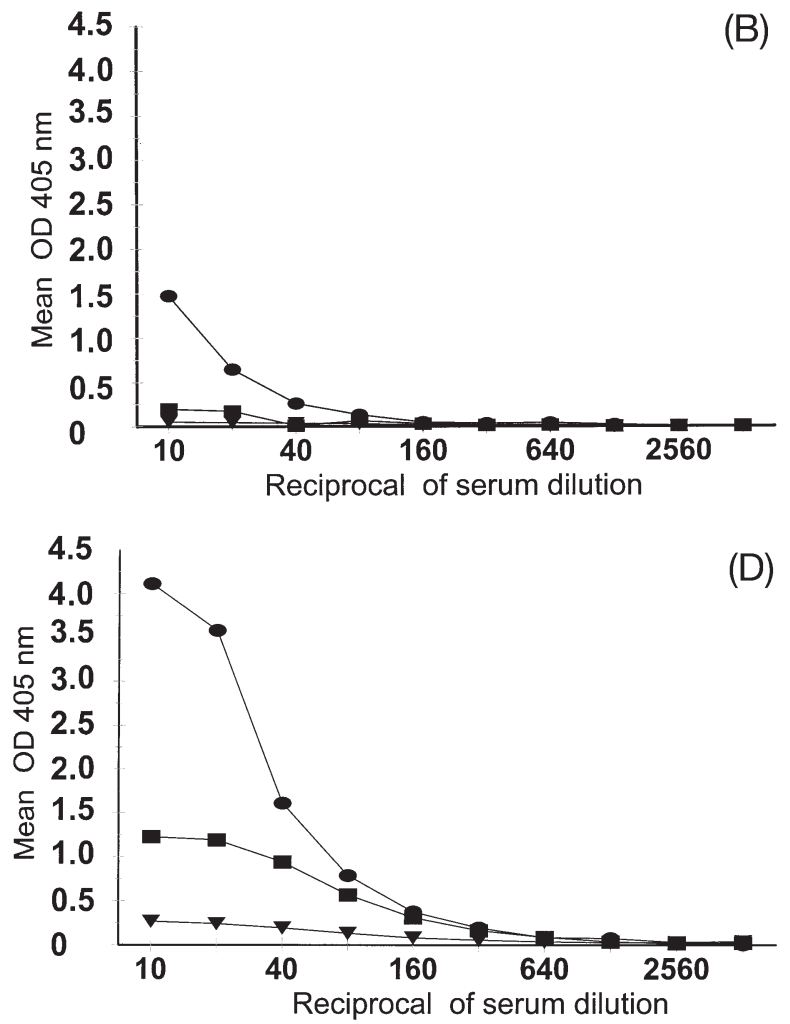

Fig. 2. Corrected mean absorbance reading in the indirect ELISA of known positive and negative fish serum samples. Data are means of triplicates $(n=3)$ of Strong ISAV-positive fish serum from naturally infected fish $(\bullet)$, weak ISAV-positive fish serum collected at 6 wk post-inoculation in experimental ISAV infection (ם), and ISAV-negative fish serum reacted on ISAV antigen-coated plates $(\boldsymbol{\nabla})$ after (A) $10 \mathrm{~min}$ incubation, (B) 40 min incubation, (C) 60 min incubation, (D) 240 min incubation, and (E) overnight incubation at $37^{\circ} \mathrm{C}$ with the enzyme substrate for alkaline phosphatase 
Table 1. Salmo salar. ELISA ISAV antibody levels in Atlantic salmon experimentally infected with ISAV. Data are corrected mean $\left( \pm\right.$ SD) optical density, OD $_{405}$. Virus: ISAV RPC/NB 990-002(4) at concentration of $1 \mu \mathrm{g}$ well ${ }^{-1}$; Cells: uninfected SHK-1 cell lysate $(1 \mu \mathrm{g}$ well ${ }^{-1}$ ); wk.p.i.: weeks post-inoculation; ${ }^{*}$ significantly higher with virus antigen than with the cellular (negative) antigen $(p<0.05)$

\begin{tabular}{|c|c|c|c|c|c|c|c|c|}
\hline \multirow[t]{3}{*}{ Dilution } & \multicolumn{8}{|c|}{ Fish serum samples } \\
\hline & \multicolumn{2}{|c|}{ Control negative serum } & \multicolumn{2}{|c|}{ Control positive serum } & \multicolumn{2}{|c|}{4 wk.p.i. } & \multicolumn{2}{|c|}{6 wk.p.i. } \\
\hline & Virus & Cells & Virus & Cells & Virus & Cells & Virus & Cells \\
\hline $1: 10$ & $0.009 \pm 001$ & $0.02 \pm 0.002$ & $4.059 \pm 0$ & $0.2 \pm 0.02$ & $0.294 \pm 0.017$ & $0.21 \pm 0.081$ & $2.84 \pm 0.13^{*}$ & $0.31 \pm 0.079$ \\
\hline $1: 20$ & $0.006 \pm 0.002$ & $0.001 \pm 0.001$ & $4.059 \pm 0$ & $0.152 \pm 0.003$ & $0.200 \pm 0.020$ & $0.145 \pm 0.033$ & $1.8 \pm 0.14^{*}$ & $0.27 \pm 0.0124$ \\
\hline $1: 40$ & & & $3.63 \pm 0.31$ & $0.142 \pm 0.001$ & $0.111 \pm 0.018$ & $0.072 \pm 0.002$ & $1.124 \pm 0.115^{*}$ & $0.113 \pm 0.0241$ \\
\hline $1: 80$ & & & $2.21 \pm 0.29$ & $0.057 \pm 0.003$ & $0.063 \pm 0.012$ & $0.043 \pm 0.008$ & $0.556 \pm 0.035^{*}$ & $0.095 \pm 0.054$ \\
\hline $1: 160$ & & & $1.451 \pm 0.11$ & $0.0512 \pm 0.001$ & $0.042 \pm 0.015$ & $0.038 \pm 0.024$ & $0.31 \pm 0.016^{*}$ & $0.061 \pm 0.038$ \\
\hline $1: 320$ & & & $0.703 \pm 0.1$ & $0.016 \pm 0.002$ & $0.024 \pm 0.006$ & $0.021 \pm 0.006$ & $0.151 \pm 0.014$ & $0.036 \pm 0.004$ \\
\hline $1: 640$ & & & $0.476 \pm 0.04$ & & $0.039 \pm 0.018$ & $0.024 \pm 0.003$ & $0.095 \pm 0.025$ & \\
\hline 1:1280 & & & $0.35 \pm 0.04$ & & & & & \\
\hline $1: 2560$ & & & $0.176 \pm 0.02$ & & & & & \\
\hline $1: 5120$ & & & $0.167 \pm 0.001$ & & & & & \\
\hline
\end{tabular}

Table 2. Salmo salar. ELISA ISAV antibody levels in Group 3A field serum samples. Data are corrected mean $( \pm \mathrm{SD}) \mathrm{OD}_{405}$ after overnight incubation. Ag: antigen (ISA virus or uninfected SHK-1 cells); ${ }^{*}$ RT-PCR positive-testing kidney tissues; ${ }^{* *}$ RT-PCR negativetesting kidney tissues (nv: not vaccinated); E-p: ELISA-positive-testing sera; nd: not done because OD was below background levels

\begin{tabular}{|c|c|c|c|c|c|c|}
\hline \multirow{2}{*}{ Fish ID/Ag } & \multicolumn{6}{|c|}{ Serum dilution } \\
\hline & 1.10 & $1: 20$ & $1: 40$ & $1: 80$ & $1: 160$ & $1: 320$ \\
\hline $\mathrm{A}^{* *} /$ Virus & $0.35 \pm 0.027$ & $0.191 \pm 0.011$ & $0.154 \pm 0.002$ & $0.104 \pm 0.001$ & $0.015 \pm 0.0$ & \\
\hline $\mathrm{A}^{* *} /$ Cells & $0.39 \pm 0.028$ & $0.146 \pm 0.005$ & $0.194 \pm 0.014$ & $0.058 \pm 0.001$ & & \\
\hline $\mathrm{B}^{* *} /$ Virus & $1.08 \pm 0.054$ & $0.79 \pm 0.054$ & $0.08 \pm 0.023$ & $0.49 \pm 0.053$ & $0.28 \pm 0.01$ & $0.181 \pm 0.012$ \\
\hline $\mathrm{B}^{* *} /$ Cells & $1.40 \pm 0.72$ & $0.69 \pm 0.011$ & $0.48 \pm 0.01$ & $0.24 \pm 0.005$ & $0.204 \pm 0.041$ & $0.106 \pm 0.006$ \\
\hline $\mathrm{D}^{* *} /$ Virus & $0.67 \pm 0.014$ & $0.481 \pm 0.007$ & $0.234 \pm 0.001$ & $0.185 \pm 0.013$ & $0.13 \pm 0.013$ & $0.057 \pm 0.01$ \\
\hline $\mathrm{D}^{* *} /$ Cells & $1.18 \pm 0.045$ & $0.73 \pm 0.001$ & $0.54 \pm 0.03$ & $0.4 \pm 0.013$ & $0.23 \pm 0.001$ & $0.121 \pm 0.013$ \\
\hline$E^{*} /$ Virus (E-p) & $1.36 \pm 0.061$ & $0.911 \pm 0.018$ & $0.623 \pm 0.007$ & $0.417 \pm 0.05$ & $0.237 \pm 0.02$ & $0.162 \pm 0.001$ \\
\hline $\mathrm{E}^{*} /$ Cells & $0.155 \pm 0.004$ & $0.0834 \pm 0.01$ & $0.086 \pm 0.002$ & $0.075 \pm 0.01$ & $0.024 \pm 0.007$ & $0.014 \pm 0.004$ \\
\hline $\mathrm{F}^{*} /$ Virus (E-p) & $2.22 \pm 0.138$ & $1.51 \pm 0.1$ & $0874 \pm 0028$ & $0.411 \pm 0.026$ & $0.3 \pm 0.021$ & $0.139 \pm 0.003$ \\
\hline $\mathrm{F}^{*} /$ Cells & $0.003 \pm 0.001$ & $0.038 \pm 0.003$ & $0.012 \pm 0.001$ & $0.0197 \pm 0.003$ & $0.025 \pm 0.004$ & \\
\hline $\mathrm{H}^{*} / \operatorname{Virus}(\mathrm{E}-\mathrm{p})$ & $2.58 \pm 0.17$ & $1.72 \pm 0.1$ & $0.82 \pm 0.011$ & $0.49 \pm 0.006$ & $0.25 \pm 0.01$ & $0.149 \pm 0.01$ \\
\hline $\mathrm{H}^{*} /$ Cells & $0.097 \pm 0.007$ & $0.046 \pm 0.005$ & $0.041 \pm 0.002$ & $0.018 \pm 0.001$ & $0.007 \pm 0.001$ & \\
\hline $\mathrm{I}^{*} / \operatorname{Virus}(\mathrm{E}-\mathrm{p})$ & $4.07 \pm 0.0$ & $4.07 \pm 0.0$ & $4.07 \pm 0.0$ & $3.94 \pm 0.18$ & $3.08 \pm 0.12$ & $2.14 \pm 0.3$ \\
\hline $\mathrm{I}^{*} /$ Cells & $0.241 \pm 0.08$ & $0.058 \pm 0.026$ & $0.02 \pm 0.006$ & & & \\
\hline $\mathrm{J}^{*} /$ Virus (E-p) & $2.04 \pm 0.126$ & $1.25 \pm 0.042$ & $0.643 \pm 0.007$ & $0.324 \pm 0.003$ & $0.133 \pm 0.007$ & $0.085 \pm 0.002$ \\
\hline $\mathrm{J}^{*} /$ Cells & $0.137 \pm 0.013$ & $0.092 \pm 0.005$ & $0.059 \pm 0.001$ & $0.038 \pm 0.001$ & $0.026 \pm 0.002$ & $0.022 \pm 0.003$ \\
\hline $\mathrm{L}^{* *} /$ Virus & $0.12 \pm 0.014$ & $0.093 \pm 0.004$ & $0.067 \pm 0.002$ & $0.03 \pm 0.0$ & & \\
\hline $\mathrm{L}^{* *} /$ Cells & nd & nd & nd & nd & & \\
\hline $\mathrm{M}^{* *} /$ Virus & $0.28 \pm 0.045$ & $0.145 \pm 0.023$ & & & & \\
\hline $\mathrm{M}^{* *} /$ Cells & $0.11 \pm 0.001$ & $0.027 \pm 0.008$ & & & & \\
\hline $\mathrm{N}^{* *} /$ Virus (nv) & $0.46 \pm 0.019$ & $0.31 \pm 0.015$ & $0.22 \pm 0.015$ & $0.171 \pm 0.001$ & $0.123 \pm 0.006$ & $0.075 \pm 0.005$ \\
\hline $\mathrm{N}^{* *} /$ Cells (nv) & $0.432 \pm 0.002$ & $0.373 \pm 0.001$ & $0.31 \pm 0.01$ & $0.133 \pm 0.004$ & $0.074 \pm 0.005$ & $0.06 \pm 0.003$ \\
\hline $\mathrm{O}^{*} /$ Virus & $0.147 \pm 0.001$ & $0.093 \pm 0.002$ & $0.063 \pm 0.005$ & $0.044 \pm 0.003$ & & \\
\hline $\mathrm{O}^{*} /$ Cells & $0.063 \pm 0.003$ & $0.043 \pm 0.001$ & $0.056 \pm 0.002$ & $0.024 \pm 0.004$ & & \\
\hline $\mathrm{P}^{* *} /$ Virus & $0.156 \pm 0.021$ & $0.1 \pm 0.016$ & $0.13 \pm 0.014$ & $0.12 \pm 0.001$ & $0.151 \pm 0.02$ & $0.11 \pm 0.03$ \\
\hline $\mathrm{P}^{* *} /$ Cells & $0.32 \pm 0.03$ & $0.22 \pm 0.03$ & $0.25 \pm 0.004$ & $0.1 \pm 0.023$ & $0.164 \pm 0.0$ & $0.058 \pm 0.008$ \\
\hline $\mathrm{Q}^{* *} /$ Virus & $0.66 \pm 0.034$ & $0.629 \pm 0.04$ & $0.4 \pm 0.06$ & $0.29 \pm 0.002$ & $0.172 \pm 0.01$ & $0.07 \pm 0.002$ \\
\hline $\mathrm{Q}^{* *} /$ Cells & $0.64 \pm 0.022$ & $0.41 \pm 0.003$ & $0.373 \pm 0.03$ & $0.168 \pm 0.02$ & $0.10 \pm 0.01$ & $0.033 \pm 0.004$ \\
\hline $\mathrm{R}^{* *} /$ Virus & $0.37 \pm 0.046$ & $0.164 \pm 0.002$ & $0.121 \pm 0.01$ & $0.055 \pm 0.001$ & $0.034 \pm 0.003$ & $0.031 \pm 0.001$ \\
\hline $\mathrm{R}^{* *} /$ Cells & $0.64 \pm 0.03$ & $0.37 \pm 0.01$ & $0.22 \pm 0.008$ & $0.12 \pm 0.012$ & $0.053 \pm 0.003$ & $0.076 \pm 0.007$ \\
\hline $\mathrm{S}^{* *} /$ Virus & $0.156 \pm 0.015$ & $0.142 \pm 0.002$ & $0.078 \pm 0.004$ & $0.066 \pm 0.006$ & $0.033 \pm 0.006$ & \\
\hline $\mathrm{S}^{* *} /$ Cells & $0.241 \pm 0.029$ & $0.122 \pm 0.07$ & $0.085 \pm 0.005$ & $0.02 \pm 0.004$ & $0.031 \pm 0.027$ & \\
\hline $\mathrm{T}^{*} /$ Virus & $0.165 \pm 0.013$ & $0.095 \pm 0.007$ & $0.083 \pm 0.007$ & $0.076 \pm 0.01$ & $0.026 \pm 0.005$ & $0.079 \pm 0.004$ \\
\hline $\mathrm{T}^{*} /$ Cells & $0.095 \pm 0.007$ & $0.083 \pm 0.007$ & $0.076 \pm 0.01$ & $0.026 \pm 0.005$ & $0.08 \pm 0.004$ & $0.12 \pm 0.02$ \\
\hline
\end{tabular}




\section{Indirect-competition ELISA}

To confirm the specificity of the indirect ELISA system for fish antibodies to ISAV, a competitive assay was set up whereby the antigen was first reacted either to rabbit anti-ISAV serum or to normal rabbit serum before adding fish sera. The results from both positive and negative fish sera reacted against viral and cellular antigens are shown in Fig. 3. The rabbit anti-ISAV serum blocked only the positive fish serum when reacted against virus antigen, as shown by the negligible OD readings.

\section{ELISA ISAV antibody levels in sera of Atlantic salmon experimentally inoculated with ISAV}

Atlantic salmon sera from uninfected control fish, and from experimental virus-infected fish at 0, 2, 4 and $6 \mathrm{wk}$ post-inoculation (p.i.) were assayed for the presence of anti-ISAV antibodies, together with the positive and negative control Atlantic salmon sera. The use of fish serum without heat-inactivation resulted in high nonspecific reactions, particularly with the cellular (negative control) antigen (data not shown). These non-specific reactions were completely eliminated if samples were heat-inactivated at $56^{\circ} \mathrm{C}$ for $30 \mathrm{~min}$. Therefore, all serum samples were heat-inactivated prior to use. Using the calculated end point of 0.24 OD units above the activity against the cellular antigen, anti-ISAV antibodies in the virus-infected experimental fish first appeared at 6 wk p.i. (Table 1). An antibody titer of 1:20 was recorded after incubation for $45 \mathrm{~min}$ with the substrate. This titre rose to 1:160 after overnight incubation. The mean OD readings at these serum dilutions were significantly higher with the virus antigen than with the cellular (negative control) antigen ( $p<0.05)$, indicating that this reaction is specific to the virus antigen and that this indirect ELISA can be used to assess the humoral response of recently infected fish.

The assay was set up such that a known positive control Atlantic salmon serum was run on each plate to ensure that the data obtained from one plate were comparable to the data obtained from other plates
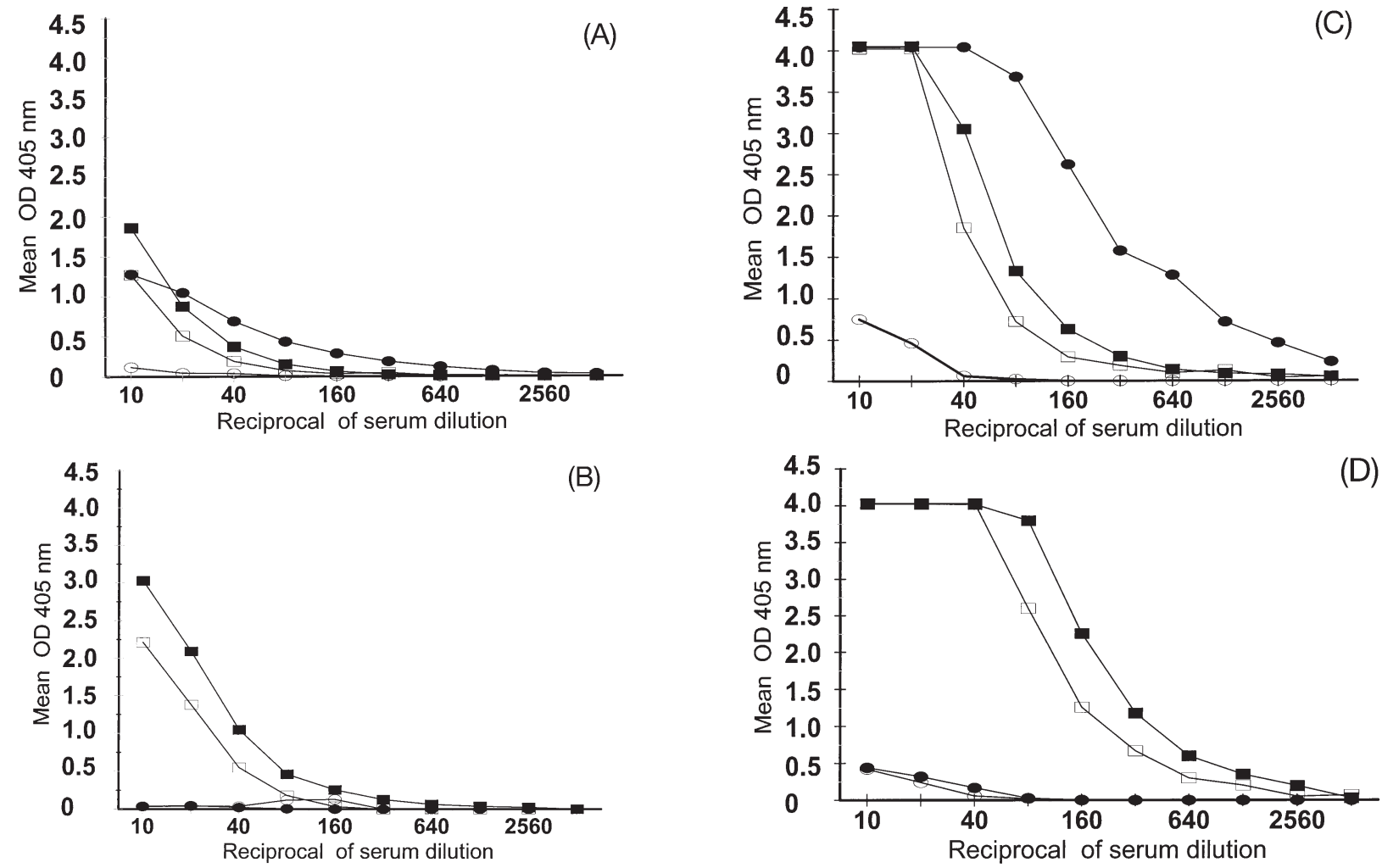

Fig. 3. Comparison of mean absorbance in ISAV-positive and -negative fish sera with or without anti-ISAV rabbit antiserum, reacted against viral and cellular antigens (A) ISAV- positive fish serum reacted on ISAV antigen coated plates after 45 min incubation with substrate; (B) ISAV-positive fish serum reacted on SHK-1 cell antigen coated plates after 45 min incubation with substrate; (C) ISAV-negative fish serum reacted on ISAV antigen coated plates after overnight incubation with substrate; (D) ISAVnegative fish serum reacted on SHK-1 cell antigen coated plates after overnight incubation with substrate. (O) OD with rabbit

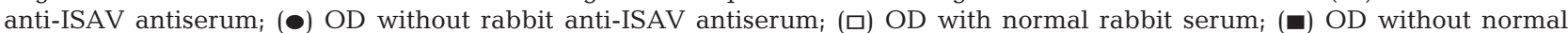
rabbit serum. Data are mean OD for each data point, assayed in triplicate 
Table 3. Salmo salar. ELISA ISAV antibody levels in Group 3B field serum samples. Data are corrected mean $( \pm \mathrm{SD}) \mathrm{OD}_{405}$ after overnight incubation. E-p: ELISA-positive-testing sera; nd: not done

\begin{tabular}{|c|c|c|c|c|}
\hline \multirow[t]{2}{*}{ Fish serum ID } & \multicolumn{2}{|c|}{ Serum dilution vs virus antigen } & \multicolumn{2}{|c|}{ Serum dilution vs SHK-1 cells } \\
\hline & $1: 10$ & $1: 20$ & $1: 10$ & $1: 20$ \\
\hline 1 & $0.573 \pm 0.036$ & $0.38 \pm 0.057$ & $1.04 \pm 0.057$ & $0.454 \pm 0.032$ \\
\hline $2(E-p)$ & $0.352 \pm 0.020$ & $0.235 \pm 0.001$ & $0.07 \pm 0.057$ & $0.089 \pm 0.002$ \\
\hline 3 & $0.14 \pm 0.005$ & $0.11 \pm 0.009$ & $0.414 \pm 0.038$ & $0.255 \pm 0.01$ \\
\hline $4(E-p)$ & $0.625 \pm 0.011$ & $0.526 \pm 0.033$ & $0.133 \pm 0.025$ & $0.105 \pm 0.021$ \\
\hline 5 & $1.07 \pm 0.037$ & $1.35 \pm 0.092$ & $0.911 \pm 0.03$ & $0.852 \pm 0.03$ \\
\hline 6 & $0.307 \pm 0.022$ & $0.484 \pm 0.01$ & $0.52 \pm 0.034$ & $0.258 \pm 0.002$ \\
\hline 7 & $0.052 \pm 0.004$ & $0.036 \pm 0.001$ & $0.266 \pm 0.024$ & $0.121 \pm 0.011$ \\
\hline $8(E-p)$ & $2.96 \pm 0.113$ & $1.69 \pm 0.13$ & $0.323 \pm 0.044$ & $0.221 \pm 0.011$ \\
\hline 9 & $0.177 \pm 0.017$ & $0.104 \pm 0.001$ & $2.03 \pm 0.18$ & $0.991 \pm 0.069$ \\
\hline 10 & $0.062 \pm 0.005$ & $0.064 \pm 0.004$ & $0.461 \pm 0.013$ & $0.274 \pm 0.0004$ \\
\hline 11 & $0.303 \pm 0.007$ & $0.186 \pm 0.014$ & $2.97 \pm 0.12$ & $1.63 \pm 0.018$ \\
\hline 12 & $0.046 \pm 0.004$ & $0.04 \pm 0.003$ & $0.095 \pm 0.001$ & $0.044 \pm 0.003$ \\
\hline 13 & $0.320 \pm 0.024$ & $0.201 \pm 0.02$ & $0.146 \pm 0.024$ & $0.153 \pm 0.002$ \\
\hline 14 & $0.036 \pm 0.001$ & $0.029 \pm 0.002$ & $0.044 \pm 0.001$ & $0.021 \pm 0.0004$ \\
\hline 15 & $0.363 \pm 0.002$ & $0.322 \pm 0.006$ & $0.261 \pm 0.006$ & $0.268 \pm 0.007$ \\
\hline 16 & $0.222 \pm 0.018$ & $0.1 \pm 0.016$ & $0.666 \pm 0.048$ & $0.229 \pm 0.01$ \\
\hline 17 & $0.762 \pm 0.03$ & nd & $0.875 \pm 0.06$ & nd \\
\hline 18 & $0.136 \pm 0.013$ & $0.138 \pm 0.001$ & $0.109 \pm 0.001$ & $0.053 \pm 0.001$ \\
\hline 19 & $0.061 \pm 0.0$ & $0.068 \pm 0.01$ & $0.655 \pm 0.09$ & $0.143 \pm 0.014$ \\
\hline 20 & $4.052 \pm 0.049$ & $3.82 \pm 0.26$ & $4.083 \pm 0.0$ & $4.083 \pm 0.0$ \\
\hline
\end{tabular}

(Tijssen 1985). A coefficient of variation was estimated from mean ODs of this positive fish serum to determine the intra-plate and inter-plate variations. Testing of the positive control fish serum to evaluate intra-plate and inter-plate variations indicated adequate repeatability (6\% coefficient of variation in both cases).

\section{ELISA ISAV antibody levels in Atlantic salmon serum samples from New Brunswick}

In ELISA assays of all field samples, the measured ODs with either virus or cellular antigens were very low after 45 min of incubation, indicating low titres of antibodies to ISAV in such samples. In fish that tested positive for ISAV by RT-PCR, the measured ODs for cellular antigens remained low (i.e. <0.24 OD) even following overnight incubations, allowing the detection of an ISAV-specific antibody response (Table 2). When the ELISA results were compared with the RTPCR results on the same fish, ELISA was able to positively identify 5 of 7 RT-PCR ISAV-positive fish, and all 10 RT-PCR negative fish were also negative in the indirect ELISA. This ELISA system was also able to differentiate between anti-ISAV antibody-positive and negative fish sera in Group 3B (Table 3).

Interestingly, in the Group 3A field samples, the sera from fish that were negative for ISAV by RT-PCR had high corrected mean ODs for both the virus and cellular antigens; particularly at low serum dilutions (Table 2). In these samples, the difference in the mean
OD between the virus and cellular antigens was invariably less than 0.24 OD units, except for Sample B at 1:80 dilution (Table 2). A similar observation was made for the ELISA-negative field sera in Group 3B (Table 3). Thus, the ELISA-negative Atlantic salmon tended to have an elevated non-specific antibody reactivity which might be suggestive of either chronic infection or resistance to ISAV infection.

\section{ISAV antibody in coho salmon serum samples from Chile}

Table 4 summarizes the VN test results and ELISA results on the coho salmon samples. Because the known negative coho salmon serum sample had a VN titre of $<1: 50$, all samples with titres of 1:50 and above were considered seropositive. Of 18 coho salmon serum samples from a clinically affected fish farm in Chile, 14 were seropositive in the VN test, with antibody titres ranging from 1:50 to 1:300. Of these, 11 were also seropositive in the ELISA test at both 1:10 and 1:20 serum dilutions. In addition, 2 of 4 samples that were seronegative in the VN test (i.e. VN titre $<1: 50$ ) were seropositive in ELISA (although one of these, Sample 15, was ELISA-positive at only 1:10 dilution) for a total of 13 of 18. Sample 14 was ELISA-positive only at 1:20 dilution (Table 4 ). The reactivity of this sample at 1:10 dilution was probably a prozone effect error (Linder \& Miettinen 1976). Sample 6 was tested only in ELISA and was seronegative. Thus the coho 
salmon serum pool samples had high reactivity to ISAV antigen.

RT-PCR testing for ISAV was also performed on this group of fish using heart, liver and kidney-tissuepooled samples. All 6 liver pools tested were positive for ISAV, as were 4 of 6 heart pools and kidney pools. However, because the sera and tissues were pooled samples, no correlation could be drawn between the antibody ELISA and RT-PCR results.

\section{DISCUSSION}

The ELISA system described here is capable of detecting antibody to ISAV in fishes, as demonstrated by application to serum samples from farmed Atlantic salmon in the Bay of Fundy, New Brunswick, Canada, and to serum samples from farmed coho salmon in Chile. Although previous studies reported increased resistance of Atlantic salmon to ISAV upon re-infection or after passive immunization with serum from fish that had recovered from ISA (Falk \& Dannevig 1995), or following vaccination with inactivated virus (Jones et al. 1999), antibody levels in such fish were not determined. Others have tried and failed to demonstrate ISAV antibody titres against ISAV in sera from vaccinated Atlantic salmon (Brown et al. 2000) or from aquarium infection experiments (King et al. unpubl. data). The indirect ELISA system developed in this study uses purified virus antigen as ELISA plate-coating antigen, and revealed 2 different types of antibody responses to ISAV by field fish. Naturally infected Atlantic salmon carrying ISAV detectable by RT-PCR had a specific antibody response to ISAV suggestive of a recent infection, whereas those that were virus-negative by RT-PCR had an elevated non-specific antibody reactivity that may be suggestive of chronic infection or resistance to ISAV. Serum from experimental fishes collected up to 6 wk p.i. did not show the elevated non-specific antibody reactivity. Comparison of the mean OD of the known positive control fish serum between the virus antigen and the SHK-1 cell lysate antigen using unpaired $t$-tests showed the test to be highly specific for antibodies to ISAV in both Atlantic salmon and coho salmon. This is the first report demonstrating specific circulating antibody in sera of fishes exposed to ISAV.

The use of fish serum without heat-inactivation resulted in high non-specific reactions, particularly with the cellular (negative) antigen. We observed that these non-specific reactions were completely eliminated if samples were heat-inactivated at $56^{\circ} \mathrm{C}$ for $30 \mathrm{~min}$. Dixon et al. (1994) inactivated carp serum for $30 \mathrm{~min}$ at $45^{\circ} \mathrm{C}$ before use in virus neutralization and competitive ELISA. Our data suggest that heat-inactivation of the fish sera at $56^{\circ} \mathrm{C}$ for $30 \mathrm{~min}$ contributed to the specificity of the assay.

Table 4. Oncorhynchus kisutch. ISAV antibody levels in coho salmon serum samples from Chile. Data are corrected mean $( \pm \mathrm{SD}) \mathrm{OD}_{405}$ after overnight incubation. E-p: ELISA-positive-testing sera; CS: control coho salmon serum samples; VN: virus neutralisation titre, expressed as highest dilution of serum to completely neutralise $100 \mathrm{TCID}_{50}$ of ISAV Isolate RPC/NB 99002-4, nd:not done

\begin{tabular}{|c|c|c|c|c|c|}
\hline \multirow{2}{*}{ Fish serum ID } & \multirow{2}{*}{ VN titre } & \multicolumn{2}{|c|}{ Serum dilution vs ISAV antigen } & \multicolumn{2}{|c|}{ Serum dilution vs SHK-1 cells } \\
\hline & & $1: 10$ & $1: 20$ & $1: 10$ & $1: 20$ \\
\hline $1(E-p)$ & $1: 50$ & $0.739 \pm 0.047$ & $0.762 \pm 0.006$ & $0.234 \pm 0.018$ & $0.184 \pm 0.007$ \\
\hline 2 & $<1: 50$ & $0.574 \pm 0.052$ & $0.472 \pm 0.003$ & $0.315 \pm 0.011$ & $0.308 \pm 0.022$ \\
\hline 3 & $1: 100$ & $1.315 \pm 0.131$ & $0.832 \pm 0.024$ & $1.270 \pm 0.092$ & $0.759 \pm 0.055$ \\
\hline 4 & $1: 100$ & $0.305 \pm 0.029$ & $0.299 \pm 0.028$ & $0.167 \pm 0.012$ & $0.132 \pm 0.020$ \\
\hline $5(E-p)$ & $1: 100$ & $2.009 \pm 0.187$ & $1.388 \pm 0.064$ & $1.541 \pm 0.107$ & $0.637 \pm 0.063$ \\
\hline 6 & nd & $0.395 \pm 0.015$ & $0.269 \pm 0.022$ & $0.202 \pm 0.001$ & $0.100 \pm 0.015$ \\
\hline $7(E-p)$ & $1: 100$ & $0.840 \pm 0.053$ & $0.802 \pm 0.051$ & $0.458 \pm 0.034$ & $0.325 \pm 0.006$ \\
\hline $8(\mathrm{E}-\mathrm{p})$ & $1: 200$ & $1.046 \pm 0.131$ & $0.838 \pm 0.071$ & $0.558 \pm 0.036$ & $0.415 \pm 0.062$ \\
\hline 9 & $1: 75$ & $0.220 \pm 0.007$ & $0.262 \pm 0.012$ & $0.142 \pm 0.004$ & $0.181 \pm 0.017$ \\
\hline $10(E-p)$ & $1: 300$ & $1.818 \pm 0.126$ & $1.804 \pm 0.047$ & $0.914 \pm 0.075$ & $0.566 \pm 0.030$ \\
\hline 11 (E-p) & $<1: 50$ & $0.598 \pm 0.028$ & $0.412 \pm 0.023$ & $0.290 \pm 0.036$ & $0.082 \pm 0.020$ \\
\hline $12(\mathrm{E}-\mathrm{p})$ & $1: 75$ & $1.651 \pm 0.116$ & $1.242 \pm 0.068$ & $0.882 \pm 0.073$ & $0.695 \pm 0.030$ \\
\hline 13 (E-p) & $1: 150$ & $1.002 \pm 0.145$ & $0.869 \pm 0.071$ & $0.234 \pm 0.014$ & $0.430 \pm 0.010$ \\
\hline 14 & $<1: 50$ & $0.388 \pm 0.044$ & $0.481 \pm 0.035(E-p)$ & $0.158 \pm 0.026$ & $0.196 \pm 0.021$ \\
\hline 15 & $1: 50$ & $0.879 \pm 0.075(E-p)$ & $0.652 \pm 0.033$ & $0.273 \pm 0.038$ & $0.560 \pm 0.034$ \\
\hline $16(E-p)$ & $1: 100$ & $3.456 \pm 0.076$ & $1.942 \pm 0.152$ & $2.259 \pm 0.154$ & $1.272 \pm 0.076$ \\
\hline 17 & $<1: 50$ & $0.382 \pm 0.024$ & $0.360 \pm 0.003$ & $0.374 \pm 0.019$ & $0.197 \pm 0.012$ \\
\hline $18(E-p)$ & $1: 50$ & $0.846 \pm 0.021$ & $0.812 \pm 0.021$ & $0.519 \pm 0.018$ & $0.450 \pm 0.052$ \\
\hline 19 (E-p) & $1: 100$ & $0.682 \pm 0.022$ & $0.666 \pm 0.001$ & $0.183 \pm 0.020$ & $0.129 \pm 0.013$ \\
\hline CS-positive (E-p) & $1: 150$ & $1.002 \pm 0.145$ & $0.869 \pm 0.071$ & $0.234 \pm 0.014$ & $0.430 \pm 0.010$ \\
\hline CS-negative & $<1: 50$ & $0.498 \pm 0.019$ & $0.441 \pm 0.033$ & $0.259 \pm 0.024$ & $0.271 \pm 0.003$ \\
\hline
\end{tabular}


Analytical specificity for the test was assessed by use of cellular antigens (uninfected SHK-1 cell lysate), since these were considered the most likely source for cross-reactions because their content in the virus antigen preparation used would depend on the degree of purity of the virus. The purity of the virus antigen was demonstrated by the presence of only the 4 characteristic viral protein bands at $74,53,43$, and $26.5 \mathrm{kDa}$ visible in Coomassie blue-stained gels (Kibenge et al. 2000a), and by the fact that the antigen successfully adsorbed to ELISA plates over a wide range of concentrations. However, while the known positive serum and known negative serum controls did not react with the uninfected SHK-1 cell lysate antigens, it was our experience that field sera from fishes that tested negative for ISAV by RT-PCR reacted relatively strongly with both the virus and the cellular antigens, particularly at low serum dilutions (Table 2). Therefore, to differentiate between the specific antibodies to ISAV and non-specific antibody reactivities, the fish sera were titrated and the end-point value was calculated for each individual serum by comparing the difference in mean OD between the virus antigen and the cellular antigens. Anti-ISAV antibody titres were calculated using a cut-off of 0.24 OD units above activity against cellular antigens. On this basis, the ELISA system was able to differentiate between an ISAV-specific antibody response (suggestive of a recent infection) and the non-specific antibody reactivity to ISAV (that might be suggestive of chronic infection or resistance to ISAV) in Atlantic salmon.

One of the reasons fish serology has not been widely used in infectious disease diagnosis is because fish immunoglobulins are predominantly of the IgM isotype, which is generally of relatively low specificity (Denzin \& Staak 2000). Denzin \& Staak (2000) suggested improving the resolution between the specific and cross-reacting fish IgM by using a competitive ELISA incorporating competing mammalian IgG or avian IgY of high affinity. However, Dixon et al. (1994) used competitive ELISA to overcome the requirement for antibodies prepared against the immunoglobulin of each fish species under test. In the present study, an indirect-competition ELISA was used to confirm specificity of the ELISA system for fish antibodies to ISAV antigens, as demonstrated by the ability of rabbit antiISAV serum to specifically block the reactivity of the positive fish serum against the virus antigen.

We interpreted the presence of specific antibody to ISAV in farmed coho salmon in Chile (Table 4) as evidence of infection with this virus, or with a crossreacting but as yet unidentified virus in coho salmon. ISAV has previously been isolated from farmed coho salmon in Chile (Kibenge et al. 2001). Tissue samples of the fish that were the source of the serum used in this study were also tested by RT-PCR for the presence of ISAV. All 6 liver pools and 4 of 6 heart pools and kidney pools tested were positive for ISAV. However, because the sera and tissues were pooled samples, no correlation could be drawn between the antibody ELISA and RT-PCR results. We believe that the presence of antiISAV antibodies in marine-farmed coho salmon in Chile, where vaccination for ISAV is not practiced, is further evidence of ISAV in farmed fish in Chile.

Examination of sera from surviving Atlantic salmon following experimental infection with ISAV showed that specific antibody was present beginning at $6 \mathrm{wk}$ p.i., indicating that the assay could be used as a routine laboratory test for detection of ISAV infection, particularly when the virus is notoriously difficult to isolate from clinical specimens, as in farmed coho salmon in Chile (Kibenge et al. 2001). Also, in instances where vaccination is not performed such as in wild fish, the test can detect asymptomatic ISAV carriers.

We therefore conclude that this ELISA system has potential for field application such as a routine laboratory test for detection of ISAV infection. Where vaccination is not performed, the test can detect asymptomatic ISAV carriers to obtain a realistic estimate of the prevalence of ISAV infection, particularly since ISAV is notoriously difficult to isolate in such circumstances. The elevated non-specific antibody reactivity in ELISA-negative field fishes suggests that the test can also be used to assess ISAV vaccine efficacy before placing smolts in sea cages, or for testing fishes in sea cages to detect level of immunity from previous infection or vaccines. Studies are now under way to determine the diagnostic sensitivity and diagnostic specificity of this ELISA system by using reference fishes of known history and infection status relative to ISAV infection, and to determine the viral proteins associated with the specific humoral response of recent infection and the non-specific humoral response of chronic infection or resistance to ISAV. It is considered that such information may lead to the production of low-cost antigens and wider use of this ELISA system.

Acknowledgements. This work was funded by a strategic grant from the Natural Sciences and Engineering Research Council (NSERC) of Canada.

\section{LITERATURE CITED}

Anonymous (2000a) ISA hits the Faroes. Fish Farming Int 27:47 Anonymous OIE (2000b) Manual of standards for diagnostic tests and vaccines, 4th edn. The Office International des Epizooties (OIE), Paris

Arkoosh MR, Kaattari SL (1990) Quantitation of fish antibody to a specific antigen by an enzyme-linked immunosorbent assay (ELISA). In: Stolen JS, Fletcher TC, Anderson DP, Roberson BS, van Muiswinkel WB (eds) Techniques in fish immunology, Chapter 3. SOS Publications, Fair Haven, NJ 
Bouchard D, Keleher W, Opitz HM, Blake S, Edwards KC, Nicholson BL (1999) Isolation of infectious salmon anaemia virus (ISAV) from Atlantic salmon in New Brunswick, Canada. Dis Aquat Org 35:131-137

Bouchard D, Brockway K, Giray C, Keleher W, Merril PL (2001) First report of infectious salmon anaemia (ISA) in the United States. Bull Eur Assoc Fish Pathol 21: $86-88$

Brown LL, Sperker SA, Clouthier S, Thornton JC (2000) Development of a vaccine against infectious salmon anaemia virus (ISAV). Bull Aquacult Assoc Can 100:4-7

Byrne PJ, MacPhee DD, Ostland VE, Johnson G, Ferguson HW (1998) Haemorrhagic kidney syndrome of Atlantic salmon Salmo salar L. J Fish Dis 21:81-91

Corbel MJ (1975) The immune response in fish: a review. J Fish Biol 7:539-563

Dannevig BH, Falk K, Namork E (1995) Isolation of the causal virus of infectious salmon anaemia (ISA) in a long-term cell line from Atlantic salmon head kidney. J Gen Virol 76: 1353-1359

Denzin N, Staak C (2000) Fish immunoglobulin-a serodiagnosticians perspective. Bull Eur Assoc Fish Pathol 20: 60-64

Devold M, Krossoy B, Aspehaug V, Nylund A (2000) Use of RT-PCR for diagnosis of infectious salmon anaemia virus (ISAV) in carrier sea trout Salmo trutta after experimental infection. Dis Aquat Org 40:9-18

Dixon PF, Hattenberger-Baudouy AM, Way K (1994) Detection of carp antibodies to spring viraemia of carp virus by a competitive immunoassay. Dis Aquat Org 19:181-186

Dorson M (1981) Role and characterization of fish antibodies. In: Hennessen W (ed) Developments in biological standardization, fish biologics and vaccines, Vol 49. Karger, Basel, p 307-319

Evensen Ø, Thorud KE, Olsen YA (1991) A morphological study of gross and light microscopic lesions of infectious anaemia in Atlantic salmon (Salmo salar). Res Vet Sci 51: 215-222

Falk K, Dannevig BH (1995) Demonstration of a protective immune response in infectious salmon anaemia (ISA)infected Atlantic salmon Salmo salar. Dis Aquat Org 21:1-5

Falk K, Namork E, Dannevig BH (1998) Characterization and applications of a monoclonal antibody against infectious salmon anaemia virus. Dis Aquat Org 34:77-85

Harlow E, Lane D (1988) Antibodies. A laboratory manual. Cold Spring Harbor Laboratory Press, Cold Spring Harbor, NY

Hattenberger-Baudouy AM, Danton M, Merle G, de Kinkelin $P$ (1995) Serum neutralization test for epidemiological studies of salmonid rhabdovirus in France. Vet Res 26: $512-520$

Jones SRM, Mackinnon AM, Salonius K (1999) Vaccination of fresh-water-reared Atlantic salmon reduces mortality associated with infectious salmon anaemia virus. Bull Eur Assoc Fish Pathol 19:98-101

Kibenge FSB, Lyaku JR, Rainnie D, Hammell LK (2000a) Growth of infectious salmon anaemia virus in CHSE-214 cells and evidence for phenotypic differences between virus strains. J Gen Virol 81:143-150

Kibenge FSB, Whyte SK, Hammell KL, Rainnie D, Kibenge MT, Martin CK (2000b) A dual infection of infectious salmon anaemia (ISA) virus and a togavirus-like virus in ISA of Atlantic salmon Salmo salar in New Brunswick, Canada. Dis Aquat Org 42:11-15

Kibenge FSB, Gárate ON, Johnson G, Arriagada R, Kibenge MJT, Wadowska D (2001) Isolation and identification of

Editorial responsibility: Jo-Ann Leong,

Corvallis, Oregon, USA infectious salmon anaemia virus (ISAV) from coho salmon in Chile. Dis Aquat Org 45:9-18

Kim CH, Leong JA (1999) Fish viruses. In: Granoff A, Webster RG (eds) Encyclopedia of virology, 2nd edn. Academic Press, San Diego, p 558-568

Lannan CN, Winton JR, Fryer JL (1984) Fish cell lines: establishment and characterization of nine cell lines from salmonids. In Vitro 20:671-676

Linder E, Miettinen A (1976) Prozone effects in indirect immunofluorescence. Scand J Immunol 5:513-519

Lovely JE, Dannevig BH, Falk K, Hutchin L, MacKinnon AM, Melville KJ, Rimstad E, Griffiths SG (1999) First identification of infectious salmon anaemia virus in North America with haemorrhagic kidney syndrome. Dis Aquat Org 35: 145-148

Marchalonis JJ (1971) Isolation and partial characterization of immunoglobulins of gold fish (Carassius auratus) and carp (Cyprius carpio). Immunology 20:161-173

Mjaaland S, Rimstand E, Falk K, Dannevig BH (1997) Genomic characterization of the virus causing infectious salmon anaemia in Atlantic salmon (Salmo salar L): an orthomyxo-virus-like virus in a teleost. J Virol 71:7681-7686

Mullins JG, Groman D, Wadwoska D (1998) Infectious salmon anaemia in salt water Atlantic salmon (Salmo salar L.) In New Brunswick, Canada. Bull Eur Assoc Fish Pathol 11: $110-114$

Nylund A, Alexandersen S, Løvik P, Jakobsen P (1994) The response of brown trout (Salmo trutta L.) to repeated challenge with infectious salmon anaemia (ISA). Bull Eur Assoc Fish Pathol 14:167-170

Nylund A, Alexandersen S, Rolland JB, Jakobsen P (1995) Infectious salmon anaemia virus (ISAV) in brown trout. J Aquat Anim Health 7:236-240

Nylund A, Kvenseth AM, Krossøy B, Hodneland K (1997) Replication of the infectious salmon anaemia virus (ISAV) in rainbow trout, Oncorhynchus mykiss (Walbaum). J Fish Dis 20:275-279

Raynard RS, Murray AG, Gregory A (2001) Infectious salmon anaemia virus in wild fish from Scotland. Dis Aquat Org 46:93-100

Rimstad E, Falk K, Mikalsen AB, Teig A (1999) Time course tissue distribution of infectious salmon anaemia virus in experimentally infected Atlantic salmon Salmo salar. Dis Aquat Org 36:107-112

Ritchie RJ, Cook M, Mellville K, Simard N, Cusack R, Griffiths S (2001) Identification of infectious salmon anaemia virus (ISAV) in Atlantic salmon from Nova Scotia (Canada): evidence for carrier fish and strain differences. Dis Aquat Org 44:171-178

Rodger HD, Richards RH (1998) Haemorrhagic smolt syndrome: a severe anaemic condition in farmed salmon in Scotland. Vet Rec 142:538-541

Sambrook J, Fritsch EF, Maniatis T (1989) Molecular cloning. A laboratory manual, 2nd edn. Cold Spring Harbor Laboratory Press, Cold Spring Harbor, NY

Thorud K, Djupvik HO (1988) Infectious anaemia in Atlantic Salmon (Salmo salar L.). Bull Eur Assoc Fish Pathol 18: 109-111

Tijssen P (1985) Laboratory techniques in biochemistry and molecular biology. In: Burdon $\mathrm{RH}$, van Knippenberg $\mathrm{PH}$ (eds) Practice and theory of enzyme immunoassays, Chapter 1. Elsevier Science Publishing Company, New York

Wergeland HI, Jakobsen RA (2001) A salmonid cell line (TO) for production of infectious salmon anaemia virus (ISAV). Dis Aquat Org 44:183-190

Wilson MR, Warr GW (1992) Fish immunoglobulins and the genes that encode them. Annu Rev Fish Dis 201-221 